\title{
INFLUENCES OF WATERSHED URBANIZATION AND INSTREAM HABITAT ON MACROINVERTEBRATES IN COLD WATER STREAMS ${ }^{1}$
}

\author{
Lizhu Wang and Paul Kaneht ${ }^{2}$
}

\begin{abstract}
We analyzed data from riffle and snag habitats for 39 small cold water streams with different levels of watershed urbanization in Wisconsin and Minnesota to evaluate the influences of urban land use and instream habitat on macroinvertebrate communities. Multivariate analysis indicated that stream temperature and amount of urban land use in the watersheds were the most influential factors determining macroinvertebrate assemblages. The amount of watershed urbanization was nonlinearly and negatively correlated with percentages of Ephemeroptera-PlecopteraTrichoptera (EPT) abundance, EPT taxa, filterers, and scrapers and positively correlated with Hilsenhoff biotic index. High quality macroinvertebrate index values were possible if effective imperviousness was less than 7 percent of the watershed area. Beyond this level of imperviousness, index values tended to be consistently poor. Land uses in the riparian area were equal or more influential relative to land use elsewhere in the watershed, although riparian area consisted of only a small portion of the entire watershed area. Our study implies that it is extremely important to restrict watershed impervious land use and protect stream riparian areas for reducing human degradation on stream quality in low level urbanizing watersheds. Stream temperature may be one of the major factors through which human activities degrade cold-water streams, and management efforts that can maintain a natural thermal regime will help preserve stream quality.

(KEY TERMS: nonpoint source pollution; watershed management; macroinvertebrate; habitat; urbanization; cold water stream; water temperature.)
\end{abstract}

Wang, Lizhu and Paul Kanehl, 2003. Influences of Watershed Urbanization and Instream Habitat on Macroinvertebrates in Cold Water Streams. Journal of the American Water Resources Association (JAWRA) 39(5):1181-1196.

\section{INTRODUCTION}

Watershed management professionals pay special attention to the influence of watershed urban development on stream ecosystems because this land use is known to substantially alter streamflow patterns, channel morphology, water quality, and biological communities (see reviews by Paul and Meyer, 2001; Wang and Lyons, 2003). One of the essential steps in watershed land use management is to identify an instream indicator that can serve as a surrogate for all the other instream perturbations resulting from urbanization and against which best-case land use scenarios can be developed.

Stream macroinvertebrate communities are commonly used as surrogate indicators because their assemblages consist of a variety of species with different life histories that are sensitive to degradation, play an important functional role in stream ecosystems, and have been found to respond to a range of urbanization effects on streams (Wang and Lyons, 2003). Macroinvertebrate assemblages represent the end point of the combined influences of hydrology, channel morphology, and water quality and quantity and have been shown to respond predictably to these factors within specific geographical regions (Wright et al., 1984). Macroinvertebrate assemblages have proven to be a relatively accurate and easily measured indicator of the overall quality of a stream ecosystem (Karr and Chu, 1999). Although a growing body of literature has documented the substantial changes in macroinvertebrate communities resulting from urban development, generalized quantitative relations between levels of urbanization in mixed agriculture and urban watersheds and the quality of macroinvertebrate communities in cold water streams have not been established. Such quantitative relations can provide insight on how instream conditions respond to the level of land use changes in the

\footnotetext{
${ }^{1}$ Paper No. 02152 of the Journal of the American Water Resources Association. Discussions are open until April 1, 2004.

2Respectively, Institute for Fisheries Research, 212 Museums Annex Bldg., 1109 North University, Ann Arbor, Michigan 48109; and Research Technician, Wisconsin Department of Natural Resources Research Center, 1350 Femrite Drive, Monona, Wisconsin 53716 (EMail/Wang: wangl@michigan.gov).
} 
watersheds, which are needed for developing best watershed land use scenarios and evaluating the effectiveness of best watershed management practices.

Another essential step in watershed management is to identify the key natural and human induced environmental factors that most strongly influence biological communities. Consequently, the best management strategies can then be developed to focus on these key factors. Studies have demonstrated that the biological composition of streams is largely influenced by localized physical and chemical factors, such as water quality, energy source, substrate, channel morphology, and flow and thermal regimes (Southwood, 1977; Minshall, 1988; Townsend and Hildrew, 1994). These localized habitats are in turn mainly determined by watershed features, such as surficial geology, soil type, bedrock type and depth, watershed topography, land cover, and climate (Richards et al., 1996; Allan and Johnson, 1997; Johnson and Gage, 1997; Wiley et al., 1997). For a specific stream type, such as small cold water streams in a relatively small geographic region, the natural variation of certain properties of biological communities are expected to be small, and any major deviation in these biological properties from natural variation can be attributed to the influence of human induced land cover changes in the watershed and activities in the stream. Although there is extensive evidence that urban land use in a watershed can dramatically modify stream physical, chemical, and hydrological properties and alter macroinvertebrate communities, there is only a limited understanding of how human induced land cover changes in a watershed influence a stream and its associated macroinvertebrate communities through multiple direct and indirect pathways operating at different spatial and temporal scales (Allan and Johnson, 1997).

Effective watershed management also requires information on the spatial distribution of land use because the locations of land uses within a watershed are likely to determine their impacts on the biological communities of a stream. Although a number of reports have examined the influence of different spatial scale agriculture/forest land uses on stream macroinvertebrates (e.g., Richards et al., 1996; Roth et al., 1996; Allan et al., 1997; Fitzpatrick et al., 2001; Sponseller et al., 2001; Stewart et al., 2001), few studies have evaluated such an influence for mixed urbanagriculture dominated watersheds. Among the limited studies, Steedman (1988) and May et al. (1997) reported that a positive relation exists between the width of forested riparian corridors and fish and invertebrate biotic integrity in urbanizing watersheds of forest regions of southern Ontario and western
Washington state. Wang et al. (2001) also found that effective imperviousness within a $50 \mathrm{~m}$ buffer along a stream or within a $1.6 \mathrm{~km}$ radius upstream of the sampling site had more influence on warm water stream fish and baseflow than did comparable amounts of imperviousness further away from the site in southeastern Wisconsin. Little is known about the difference of such a spatial influence for mixed urbanand agriculture dominated watersheds for macroinvertebrates in cold water streams.

In this study, we analyzed 39 small cold water watersheds along an urban/agriculture land use gradient for stream macroinvertebrate communities and watershed land uses to describe relations between urban land use and some of the key macroinvertebrate indicators. These relations can provide tools for evaluating the effectiveness of urban best management practices and for predicting future stream conditions for planned urban development so that land use scenarios can be prioritized. We also identified key environmental factors that were strongly correlated with macroinvertebrate composition to identify the dominant land uses and instream habitats in order to explore the linkage among watershed, riparian corridor, and instream features and their influence on biological communities. Additionally, we evaluated the relative importance of different spatial scales of land use in influencing stream macroinvertebrate communities. This analysis provides information useful for watershed researchers, managers, and planners to assist in prioritizing landscape development locations so that more sensitive areas in the watershed can be protected and urban impacts on streams can be minimized.

\section{METHODS}

\section{Study Area}

The study streams (Figure 1) were chosen to include watersheds that had a range of urban land use in Wisconsin and eastern Minnesota. These streams were either presently designated as trout streams by state agencies or were not currently considered trout streams but had historically contained self-sustained trout populations. These stream selection criteria not only met the need for the macroinvertebrate study but also satisfied a parallel study for evaluating urban impacts on cold water fishes (Wang et al., 2003). We chose some streams in Minnesota because we had prescreened all possible cold water streams that have some extent of urban land use in the watersheds and we did not have a sufficient 


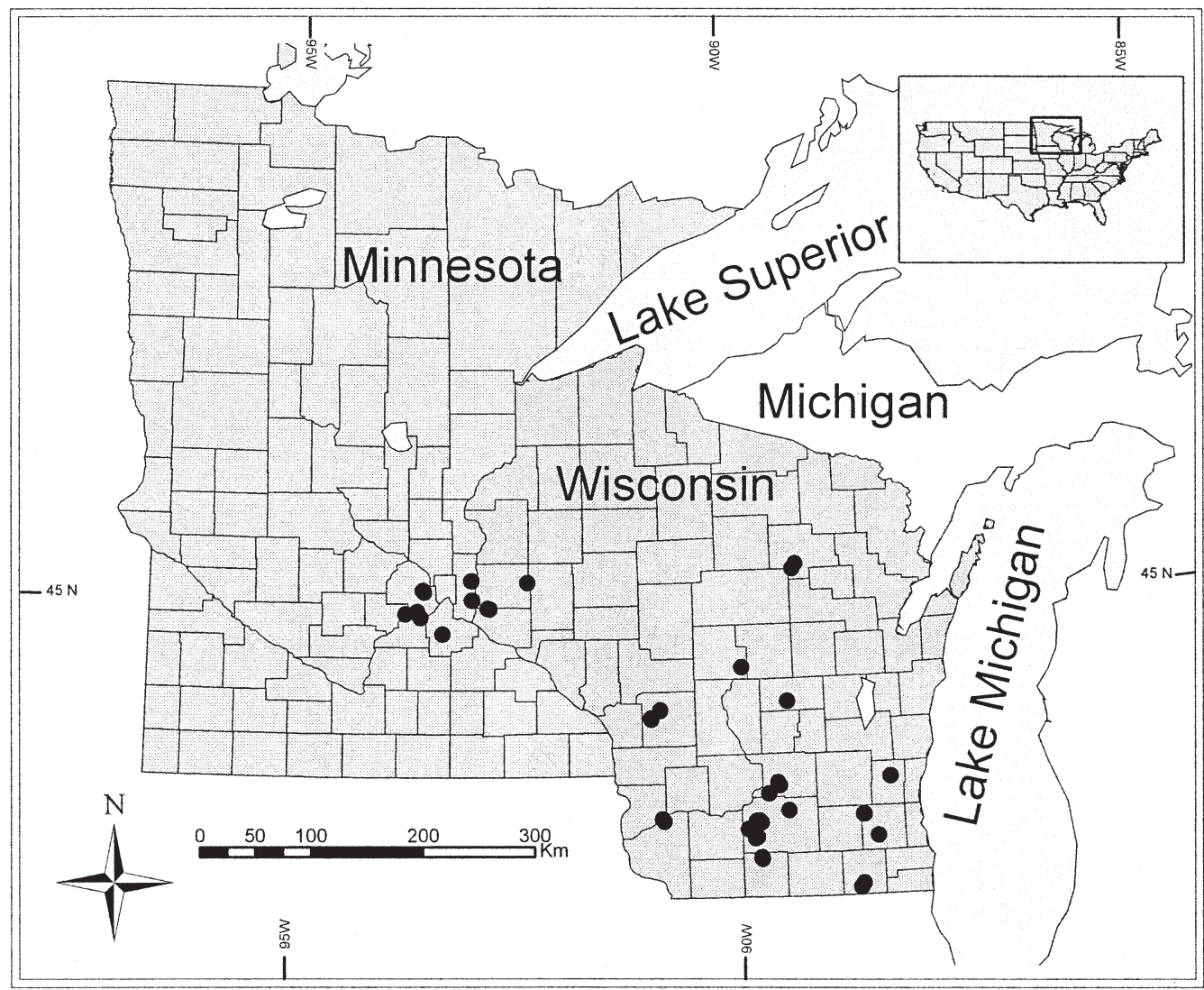

Figure 1. Map of Wisconsin and Minnesota Showing the Sampling Locations.

number of watersheds with high levels of urban land use in Wisconsin.

A single stream site was sampled within each of the 39 watersheds. All the sites were chosen to minimize potential natural variation, such as thermal and hydrological regimes, which may influence biological attributes, while maximizing variation in the amount of urban land use. In the absence of different watershed land uses, these cold water stream sites would be expected to have similar physical habitat, thermal and hydrological regimes, and biological communities (Lyons, 1996).

\section{Habitat Assessment}

Stream physical habitat, baseflow, and water temperature were measured at each site during 1999 or 2000. Because macroinvertebrate composition is more strongly correlated with segment scale and reach scale environmental characteristics than physical features at the point where the macroinvertebrates were sampled (Carter et al., 1996), we assessed stream habitat at a site length of about 35 times mean stream width, or a minimum of $100 \mathrm{~m}$. Such a site length was sufficient to encompass about three meander sequences and has commonly been used for fish habitat assessment (Simonson et al., 1994; Wang et al., 1996). We established the sampling sites more than $30 \mathrm{~m}$ away from bridges or culverts to avoid the influence of these artificial obstructions.

We sampled stream physical habitat during June and July 1999 for most sites and July 2000 for 11 sites, when low streamflows facilitated effective sampling. At each site, 30 habitat variables encompassing channel morphology, bottom substrates, cover, bank conditions, riparian vegetation, and land use were measured or visually estimated along 12 transects using standardized procedures (Simonson et al., 1994).

Stream water temperature was recorded at a location near the downstream end of each site using an Onset StowAway temperature data logger. The water temperature was recorded every 30 minutes between late May and early October of 2000. Stream baseflow was measured at a single transect near the downstream end of each site using a Flow-Mate model 
2000 portable flow meter. All flow measurements were made during a four-day period in late October 2000, when flows were likely to have been at or near their annual minimum based on gaged sites in the region. No rainfall had occurred for at least 10 days before this sampling.

\section{Macroinvertebrate Sampling}

Two types of macroinvertebrate samples were collected from each site using a $600 \mathrm{~mm}$ mesh D-frame kick net in early October 2000 following the procedures described by Hilsenhoff (1987). All sampling occurred at baseflow conditions. The first sample was collected from riffles or other rocky substrates; if rocky substrates were not present, then snags were sampled to ensure the sample was from the most representative habitat at each site. The second sample was collected only from snags such as overhanging grasses, logs, woody debris, and leaf packs to ensure that these data were comparable across all the sites because rocky substrates were not present at all study sites.

The riffle or rocky substrate samples were collected by placing the net on the stream bottom and kicking an area immediately upstream of the net so that the macroinvertebrates were dislodged and washed into the net. In addition, individual rocks were picked up and the attached macroinvertebrates were removed. This process was repeated in at least three locations within the same riffle or different riffles until approximately 125 organisms with available tolerance values were collected. The snag samples were collected by placing a net in the water column where it would collect most of the dislodged debris. The snags were disturbed by scraping them with the net or shaking them by hands or feet. At each site, all available snag types and multiple locations were sampled with first consideration given to larger snags with higher water velocity until approximately 125 organisms with available tolerance values were collected. In areas with extremely low habitat diversity or low macroinvertebrate abundance, the sampling effort was continued until all the habitats within the sampling site were sampled or a total of 1.5 person hours was reached. The materials collected in the sampling net were rinsed in the stream to remove fine sediments. Large debris in the net was hand scraped to wash off macroinvertebrates and then discarded. All remaining materials in the net were placed in a sampling bottle with 80 percent ethanol.

The macroinvertebrate identification was done by faculty and students at the entomology laboratory of the University of Wisconsin-Stevens Point through a contract between the university and the Wisconsin Department of Natural Resources. In the laboratory, the samples were placed in a glass pan positioned over a grid comprising $6.5 \mathrm{~cm}^{2}$ squares. Grid squares were randomly chosen to separate macroinvertebrates from other materials until a minimum of 125 organisms with tolerance values were picked or the entire sample was sorted. All the other organisms without tolerance value in the selected grid squares were also picked. All the picked organisms were counted and identified to species or to the lowest taxonomic level possible.

\section{Watershed and Riparian Land Use Delineation}

We delineated watershed boundaries upstream of each sampling site using the ARC/VIEW automated procedures based on a Digital Elevation Model with a $30 \mathrm{~m}$ resolution. These watershed boundaries were then manually verified and corrected by referencing 1:24,000 digital topographic maps. We quantified the land uses within each watershed upstream of the sampling site by overlaying catchment boundaries on top of the Wisconsin Initiative for Statewide Cooperation on Landscape Analysis and Data (WISCLAND). The WISCLAND is a satellite derived land cover map that was originated in 1992 for Wisconsin and was collected by the Landsat Thematic Mapper with a $30 \mathrm{~m}$ ground resolution using ARC/INFO software (Lillesand et al., 1998).

We digitized effective impervious areas in watersheds and land uses in 0 to $10 \mathrm{~m}, 10$ to $20 \mathrm{~m}$, and 20 to $30 \mathrm{~m}$ buffers from digital orthophoto quadrangles using ARC/VIEW software with ground truth verification when needed. The digital orthophoto quadrangles were produced from 1992 (1:40,000 scale) and 1995 (1:19,200 scale) National Aerial Photography Program (Wisconsin Department of Natural Resources, unpublished data) with a resulting ground resolution $1 \mathrm{~m}$ or less. This high resolution digital orthophotography provided detailed urban land use in the watershed and in stream buffers. We considered all streets, sidewalks, parking lots, rooftops connected with pavement driveways, and driveways as effective impervious area. We did not use WISCLAND to generate watershed imperviousness and buffer land use data because its $30 \mathrm{~m}$ resolution was too coarse for identifying urban imperviousness and buffer land uses. We did not digitize all the watershed land uses from the digital orthophotography because the digitizing process was too time consuming and costly. 


\section{Data Summary}

We summarized the 31 WISCLAND watershed land use types into nine major categories, including agriculture, barren (land with limited ability to support life), grass, urban, water, wetland, woodland, other land, and vegetated land (grass + woodland) (Table 1). Each land category was expressed as a percentage of total watershed land use. We also expressed impervious land as a percent total watershed area because imperviousness is an excellent integrative measure of the extent and intensity of urbanization (Schueler, 1994; Arnold and Gibbons, 1996; Wang and Lyons, 2003). The different land use types (crop, grass, pasture, urban, water, wetland, wood, vegetated) within the 0 to $10 \mathrm{~m}, 10$ to $20 \mathrm{~m}$, and 20 to $30 \mathrm{~m}$ buffers and beyond the $30 \mathrm{~m}$ buffer in the watersheds (Table 1) were each expressed as a percentage of total land uses to test if the locations of the land uses had different effects on stream characteristics.

From the habitat data, we summarized means for variables (Table 2) that had been shown to influence macroinvertebrate composition (e.g., Merritt and Cummins, 1984) from the numerous instream physical habitat measurements for each site. For baseflows, we calculated a value adjusted for differences among sites in the sizes of their watersheds. Our adjusted values were expressed as the quotient of the measured baseflow divided by the watershed area. Such an adjusted baseflow is relatively consistent for streams with similar amounts of groundwater inputs and can be used to measure baseflow changes resulting from watershed land modification (Klein, 1979; Seelbach et al., 1997; Wang et al., 2001). From the water temperature data we calculated the maximum daily mean, instantaneous minimum and maximum during the measurement period, maximum and minimum of the first three weeks of July, and maximum and minimum of seven-day mean. We also calculated the differences between instantaneous maximum and minimum, between maximum and minimum of the first three weeks of July, and between maximum and minimum of seven-day means. These are temperature measurements that best reflect thermal impairment by watershed land modification in the Midwestern United States (Seelbach et al., 1997).

From the macroinvertebrate data, we calculated the Hilsenhoff biotic index (HBI), which is an index calculated based on the tolerance value of each macroinvertebrate taxon (Hilsenhoff, 1987). The index values could range from 0 to 10 , with higher values indicating more degraded water quality. The index was developed for Wisconsin streams and has been widely used in many other areas in the United
States. We also determined the total number of taxa; percentages of taxa and individuals for Ephemeroptera, Plecoptera, and Trichoptera (EPT); percentages of individuals for the two most numerous taxa, depositional taxa, Chironomidae, gatherers, filterers, herbivores, predators, scrapers, and shredders. These macroinvertebrate measures have been shown to be sensitive to nonpoint source pollution (e.g., Kerans and Karr, 1994; Karr and Chu, 1999; Stepenuck et al., 2002).

\section{Statistical Analysis}

Because only a small number of the stream sites (20 percent) contained shredders and the percentage did not show any correlation with environmental variables during a preliminary data evaluation, we did not include this variable in further data analyses.

We used a two-step approach to describe the environment macroinvertebrate relation and to evaluate the relative influence of different scales of land uses on macroinvertebrate communities. In Step 1, we first performed canonical correspondence analysis (CCA) with the forward selection procedure using CANOCO (ter Braak and Smilauer, 1998) on log transformed data to select habitat variables, land uses in the three buffer zones, and land use in watershed that were significantly $(\mathrm{p}<0.05)$ correlated with the macroinvertebrate axes. We then conducted CCA again using the selected variables to identify the major environmental factors that determined stream macroinvertebrate compositions. Lastly, we visually examined relations among the major environmental features and the key macroinvertebrate variables.

In Step 2, we first conducted redundancy analysis (RDA) using partition procedures (CANOCO software) (ter Braak and Smilauer, 1998) to determine the relative influences of all land uses collectively within the $30 \mathrm{~m}$ buffer and outside the $30 \mathrm{~m}$ buffer on macroinvertebrate compositions. We then, using the same analysis procedures, evaluated the relative influences of land uses in 0 to $10 \mathrm{~m}, 10$ to $20 \mathrm{~m}$, and 20 to $30 \mathrm{~m}$ buffers on the various macroinvertebrate measures.

\section{RESULTS}

\section{Watershed Land Use and Instream Habitat}

The study watersheds spanned a range of urban and agricultural land uses (Table 1). The urban land use upstream of the sampling sites ranged from less 
WANG AND KANEHL

TABLE 1. Watershed and Riparian Land Use Variables (mean, standard error [SE] of the mean, maximum, minimum, and median) Used in the Canonical Correspondence Analysis (CCA) for Evaluating the Influence of Land Use on Stream Macroinvertebrate Communities.

\begin{tabular}{|c|c|c|c|c|}
\hline Variable Description & Mean + 1 SE & Minimum & Maximum & Median \\
\hline \multicolumn{5}{|c|}{ Watershed Area and Land Uses } \\
\hline Percent of Agricultural & $36.8 \pm 3.2$ & 1.0 & 78.0 & 38.9 \\
\hline Percent of Barren ${ }^{1}$ & $1.3 \pm 0.2$ & 0.0 & 6.0 & 0.9 \\
\hline Percent of Grass & $15.2 \pm 1.7$ & 0.1 & 39.4 & 13.3 \\
\hline Percent of Impervious 1,2 & $5.4 \pm 1.1$ & 0.9 & 32.0 & 2.9 \\
\hline Percent of Other & $1.2 \pm 0.4$ & 0.0 & 7.8 & 0.0 \\
\hline Percent of Urban & $11.8 \pm 3.0$ & 0.1 & 82.2 & 3.2 \\
\hline Percent of Vegetated & $42.9 \pm 2.9$ & 7.2 & 78.7 & 43.2 \\
\hline Percent of Water & $0.7 \pm 0.2$ & 0.0 & 7.0 & 0.2 \\
\hline Percent of Wetland ${ }^{2}$ & $4.6 \pm 0.7$ & 0.0 & 17.6 & 2.9 \\
\hline Percent of Wood & $27.7 \pm 2.4$ & 4.3 & 56.4 & 26.1 \\
\hline Watershed area $\left(\mathrm{km}^{2}\right)$ & $36.7 \pm 5.3$ & 3.5 & 153.1 & 36.7 \\
\hline \multicolumn{5}{|c|}{ Riparian Land Uses (0-10 m) } \\
\hline Percent of Crop & $18.6 \pm 2.8$ & 0.0 & 55.0 & 15.4 \\
\hline Percent of Grass & $29.6 \pm 2.4$ & 4.8 & 54.8 & 31.8 \\
\hline Percent of Pasture & $1.7 \pm 0.4$ & 0.0 & 10.5 & 0.5 \\
\hline Percent of Urban & $4.8 \pm 1.0$ & 0.0 & 32.1 & 2.2 \\
\hline Percent of Vegetated & $65.9 \pm 3.2$ & 17.4 & 93.4 & 71.0 \\
\hline Percent of Water & $1.6 \pm 0.4$ & 0.0 & 9.7 & 0.4 \\
\hline Percent of Wetland & $7.5 \pm 2.3$ & 0.0 & 74.5 & 0.0 \\
\hline Percent of Wood & $35.7 \pm 2.8$ & 8.0 & 68.1 & 33.7 \\
\hline \multicolumn{5}{|c|}{ Riparian Land Uses (10-20 m) } \\
\hline Percent of Crop & $22.4 \pm 2.9$ & 0.0 & 54.7 & 21.5 \\
\hline Percent of Grass & $29.6 \pm 2.4$ & 4.8 & 57.4 & 29.7 \\
\hline Percent of Pasture & $2.4 \pm 0.7$ & 0.0 & 23.5 & 0.7 \\
\hline Percent of Urban & $6.4 \pm 1.2$ & 0.0 & 31.2 & 3.9 \\
\hline Percent of Vegetated & $61.8 \pm 3.0$ & 18.6 & 92.9 & 65.7 \\
\hline Percent of Water & $1.6 \pm 0.4$ & 0.0 & 11.1 & 0.3 \\
\hline Percent of Wetland & $5.2 \pm 2.3$ & 0.0 & 51.5 & 0.0 \\
\hline Percent of Wood & $32.2 \pm 2.7$ & 0.0 & 68.1 & 33.7 \\
\hline \multicolumn{5}{|c|}{ Riparian Land Uses (20-30 m) } \\
\hline Percent of Crop & $22.7 \pm 3.1$ & 0.0 & 57.4 & 20.0 \\
\hline Percent of Grass & $28.7 \pm 2.2$ & 4.8 & 48.6 & 28.2 \\
\hline Percent of Pasture & $1.9 \pm 0.4$ & 0.0 & 10.4 & 0.7 \\
\hline Percent of Urban & $9.0 \pm 1.7$ & 0.1 & 43.4 & 4.8 \\
\hline Percent of Vegetated ${ }^{2}$ & $60.3 \pm 2.7$ & 21.1 & 92.2 & 60.8 \\
\hline Percent of Water & $1.1 \pm 0.2$ & 0.0 & 6.1 & 0.2 \\
\hline Percent of Wetland & $4.9 \pm 1.5$ & 0.0 & 44.2 & 0.0 \\
\hline Percent of Wood & $31.6 \pm 2.2$ & 9.4 & 64.1 & 29.9 \\
\hline
\end{tabular}

1, 2Indicate variables that were retained by the CCA forward selection procedures and used for further CCA analysis; (1) for the riffle data set and (2) for the snag data set (see text for details).

than 1 percent to 82 percent with a mean of 12 percent, and agriculture ranged from 1 percent to 78 percent with a mean of 37 percent. The proportions of these two types of land uses in the watersheds were inversely correlated (Spearman's correlation $\mathrm{r}=-0.62$, $\mathrm{p}<0.01$ ). The study watersheds also had a range of vegetated land ( 7 percent to 79 percent, with a mean of 43 percent) and water and wetland ( 0 percent to 18 percent, with a mean of 5 percent). The vegetated land was not correlated with water or wetland $(\mathrm{p}>$ 0.05 ). Percentages of urban land in the watersheds were negatively correlated with vegetated land $(r=$ 
TABLE 2. The Instream Habitat Variables (mean, standard error [SE] of the mean, maximum, minimum, and median) Used in the Canonical Correspondence Analysis (CCA) for Evaluating the Influence of Habitat on Stream Macroinvertebrate Communities.

\begin{tabular}{|c|c|c|c|c|}
\hline Variable Description & Mean + 1 SE & Minimum & Maximum & Median \\
\hline \multicolumn{5}{|c|}{ Channel Morphology } \\
\hline Bankfull Depth (m) & $0.99 \pm 0.06$ & 0.45 & 1.85 & 0.94 \\
\hline Bankfull Width (m) & $6.66 \pm 0.36$ & 3.05 & 12.26 & 6.89 \\
\hline Bank Erosion (percent) & $21.2 \pm 2.0$ & 0.4 & 63.3 & 20.0 \\
\hline Mean Stream Width (m) & $4.64 \pm 0.29$ & 2.11 & 9.92 & 4.59 \\
\hline Mean Water Depth (m) & $0.33 \pm 0.02$ & 0.11 & 0.61 & 0.28 \\
\hline Mean Water Depth at Thalweg $(\mathrm{m})^{1}$ & $0.42 \pm 0.03$ & 0.16 & 0.75 & 0.37 \\
\hline Percent of Stream Site That Are Pools & $7.3 \pm 1.5$ & 0.0 & 35.4 & 3.8 \\
\hline Percent of Stream Site That Are Riffles & $13.0 \pm 2.3$ & 0.0 & 42.4 & 10.4 \\
\hline Percent of Stream Site That Are Runs & $79.6 \pm 2.6$ & 27.3 & 100.0 & 79.8 \\
\hline Stream Gradient $(\mathrm{m} / \mathrm{km})$ & $3.49 \pm 0.39$ & 0.00 & 9.45 & 2.90 \\
\hline Sinuosity 1,2 & $1.24 \pm 0.04$ & 0.64 & 2.21 & 1.16 \\
\hline Stream Width/Depth Ratio & $11.6 \pm 0.7$ & 5.9 & 23.6 & 11.1 \\
\hline \multicolumn{5}{|c|}{ Substrate, Cover, and Shading } \\
\hline Depth of Sand or Silt Sediment (cm) & $12.0 \pm 1.1$ & 1.0 & 37.2 & 11.3 \\
\hline Percent of Bedrock Substrate & $1.2 \pm 0.8$ & 0.0 & 29.7 & 0.0 \\
\hline Percent of Boulder Substrate & $3.4 \pm 0.7$ & 0.0 & 15.5 & 1.3 \\
\hline Percent of Canopy Shading & $54.0 \pm 4.1$ & 0.2 & 90.8 & 58.8 \\
\hline Percent of Clay Substrate & $5.3 \pm 1.4$ & 0.0 & 47.7 & 1.3 \\
\hline Percent of Cover (measured as fish cover) & $13.0 \pm 2.5$ & 0.6 & 91.6 & 10.2 \\
\hline Percent of Detritus Substrate ${ }^{1}$ & $5.3 \pm 1.2$ & 0.0 & 27.7 & 1.9 \\
\hline Percent of Gravel Substrate ${ }^{2}$ & $20.2 \pm 2.8$ & 0.0 & 64.5 & 20.2 \\
\hline Percent of Other Substrate & $0.7 \pm 0.4$ & 0.0 & 11.9 & 0.0 \\
\hline Percent of Rock Substrate Embedded by Sand or Silt & $67.9 \pm 4.0$ & 18.4 & 100.0 & 72.1 \\
\hline Percent of Rubble/Cobble Substrate & $7.1 \pm 1.5$ & 0.0 & 42.9 & 3.3 \\
\hline Percent of Sand Substrate & $40.6 \pm 4.0$ & 5.2 & 93.9 & 36.0 \\
\hline Percent of Silt Substrate & $16.1 \pm 2.5$ & 0.6 & 60.4 & 11.0 \\
\hline Percent of Stream Bottom Covered With Algae ${ }^{1}$ & $1.6 \pm 0.5$ & 0.0 & 15.1 & 0.0 \\
\hline Percent of Stream Bottom Covered With Macrophytes & $6.9 \pm 2.1$ & 0.0 & 66.7 & 1.3 \\
\hline Sum of Percentage of Gravel, Rubble/Cobble, and Boulder & $30.7 \pm 3.8$ & 0.0 & 77.3 & 26.0 \\
\hline Sum of Percentage of Silt, Sand, and Detritus & $62.0 \pm 4.0$ & 11.7 & 99.6 & 69.9 \\
\hline \multicolumn{5}{|c|}{ Water Quality, Flow, and Temperature } \\
\hline Conductivity $(\mu \mathrm{s} / \mathrm{cm})^{2}$ & $527 \pm 24$ & 158 & 807 & 548 \\
\hline Dissolved Oxygen $(\mu \mathrm{g} / \mathrm{l})$ & $9.0 \pm 0.3$ & 5.2 & 11.0 & 9.4 \\
\hline Flow $\left(\mathrm{m}^{3} / \mathrm{s} / 1000 \mathrm{~km}^{2}\right)$ & $7.8 \pm 1.6$ & 0.3 & 45.7 & 5.9 \\
\hline Temperature Daily Mean Maximum & $20.2 \pm 0.5$ & 14.3 & 27.9 & 20.5 \\
\hline Temperature Daily Range (daily maximum/minimum) & $8.4 \pm 0.3$ & 4.2 & 14.8 & 8.1 \\
\hline Temperature Instantaneous Maximum & $23.4 \pm 0.5$ & 17.5 & 30.2 & 23.2 \\
\hline Temperature Maximum for First Three Weeks of July & $22.9 \pm 0.5$ & 14.3 & 30.2 & 22.5 \\
\hline Temperature Minimum for First Three Weeks of July ${ }^{1}$ & $17.8 \pm 0.5$ & 11.8 & 26.0 & 17.6 \\
\hline Temperature Range (July maximum/minimum) & $6.5 \pm 0.2$ & 2.5 & 10.1 & 6.7 \\
\hline Temperature Seven-Day Maximum 1,2 & $18.6 \pm 0.5$ & 13.5 & 27.2 & 18.6 \\
\hline Temperature Seven-Day Minimum & $11.1 \pm 0.3$ & 7.1 & 13.9 & 11.4 \\
\hline Temperature Seven-Day Range (maximum/minimum) & $7.2 \pm 0.3$ & 4.0 & 11.5 & 6.9 \\
\hline
\end{tabular}

1, 2Indicate variables that were retained by the CCA forward selection procedures and used for further CCA analysis; (1) for the riffle data set and (2) for the snag data set (see text for details). 
$-0.48, \mathrm{p}<0.01)$ but not correlated with water or wetland. Percentages of agriculture in the watershed were significantly correlated with water and wetland $(\mathrm{r}>-0.40, \mathrm{p}<0.05)$ but not correlated to vegetated land ( $\mathrm{p}>0.05)$.

Buffer land use was partially related to watershed land use. The proportions of urban and agricultural land uses in each of the three buffer zones were correlated with land use in the watershed. Spearman's correlations for agriculture and urban land uses ranged from 0.41 to 0.77 ( $p<0.01)$. However, vegetated, water, and wetland lands in the buffers were not correlated with land uses in the watershed ( $p>0.05$ ). Percentages of particular land uses were highly correlated among the three buffer areas. Spearman's correlations were 0.78 to 0.88 for urban, 0.80 to 0.95 for agriculture, 0.87 to 0.91 for vegetated land, and 0.94 to 0.99 for water and wetland.

The sampling sites also had a range of physical habitat and water quality (Table 2). Stream gradients varied from near flat to $9.5 \mathrm{~m} / \mathrm{km}$ (mean $=3.5)$, mean stream width from 2.1 to $9.9 \mathrm{~m}$ (mean $=4.6)$, bank erosion from less than 1 to 63 percent (mean $=21$ percent), and pool habitat from 0 to 35 percent (mean $=7$ percent). Stream substrates varied considerably. The sum of gravel, cobble rubble, and boulder (i.e., rocky substrate) from 0 to 77 percent (mean $=31$ percent), the sum of silt, sand, and detritus (i.e., fine substrate) ranged from 12 to 100 percent (mean $=62$ percent), and the depth of sand and silt sediments from 1 to 37 $\mathrm{cm}($ mean $=12 \mathrm{~cm})$. Water quality and other physical properties also varied substantially. Conductivity ranged from 158 to $807 \mu \mathrm{s} / \mathrm{cm}($ mean $=527)$, dissolved oxygen ranged from 5 to $11 \mathrm{mg} / \mathrm{l}($ mean $=9$ ); water discharge ranged from 0.3 to $45.7 \mathrm{~m}^{3} / \mathrm{s} / 1000 \mathrm{~km}^{2}$, daily mean and maximum instantaneous water temperature from 14 to $28^{\circ} \mathrm{C}$ (mean $=20$ ) and 18 to $30^{\circ} \mathrm{C}$ $($ mean $=23)$, respectively.

\section{Macroinvertebrate Communities}

We found a variety of macroinvertebrate communities in the study streams (Table 3 ). We collected 79 taxa in the riffle and 97 in the snag samples. About 6 percent of the streams had less than 10 taxa, and 40 percent had more than 20 taxa. The number of EPT taxa ranged from 2 to 11 (mean $=6.6$ ) in riffle and 1 to 19 (mean $=6.1)$ in snag samples. The percentages of EPT individuals varied between 2 and 78 percent (mean $=35$ percent) for riffle and 1 and 89 percent (mean $=36$ percent) for snag samples. According to HBI scores (Hilsenhoff, 1987), about 77 percent of the streams had good to excellent condition (HBI < 5.50), 13 percent had fairly poor to poor condition (HBI =
5.51-7.50), and none of them was in very poor condition $(\mathrm{HBI}>8.51)$.

\section{Influence of Watershed and Instream Factors on Macroinvertebrate Communities}

The first CCA forward selection procedure showed that eight of the 76 environmental variables were significantly $(\mathrm{p}<0.05)$ correlated with macroinvertebrate axes for riffle samples and seven of the 76 variables were correlated with snag samples (Tables 1 and 2). Maximum weekly water temperature, watershed imperviousness, and channel sinuosity were correlated with both riffle and snag samples. Algal and detritus substrates, watershed barren land, and water depth were correlated with riffle samples only. Watershed wetland, gravel substrate, water conductivity, and vegetated land within the riparian area were correlated with snag samples only.

In the second CCA analysis, the selected environmental variables explained 61 percent of the variation for the macroinvertebrate communities from the riffle habitat (Table 4). The first CCA axis showed that watershed imperviousness, stream temperature, and detritus were positively associated with gatherer macroinvertebrates and negatively associated with percentages of EPT individuals, scrapers, filterers, and EPT taxa. The second CCA axis indicated that stream temperature and watershed imperviousness were negatively correlated with percent EPT taxa and positively correlated with HBI and percentages of herbivores, predators, and Chironomidae. The third CCA axis showed that stream temperature and barren land were negatively associated with percent EPT individuals. A plot of the first and second CCA axes identified that stream temperature and watershed urban development were major environmental factors associated with riffle macroinvertebrate communities (Figure 2).

The second CCA analysis on the samples from snag habitat showed that the selected environmental variables explained 48 percent of the variation for the macroinvertebrate communities (Table 4). The first CCA axis indicated that stream temperature, conductivity, and watershed imperviousness positively correlated with percent gatherers and negatively correlated with percentages of EPT individuals, filterers, scrapers, and number of taxa. The second CCA axis showed that stream temperature and watershed imperviousness positively correlated with percent predators and HBI scores. The third CCA axis showed that gravel substrate, stream sinuosity, and watershed wetland were negatively associated with percentages of the two most numerous taxa individuals. 
TABLE 3. The Macroinvertebrate Variables (mean, standard error [SE] of the mean, range, and median) Used in the Canonical Correspondence Analysis for Evaluating the Influence of Watershed

Land Uses and Instream Habitat on Macroinvertebrate Communities.

\begin{tabular}{|c|c|c|c|c|c|c|c|c|c|c|}
\hline \multirow[b]{2}{*}{ Variable Description } & \multicolumn{5}{|c|}{ Riffle Sample } & \multicolumn{5}{|c|}{ Snag Sample } \\
\hline & \multicolumn{2}{|c|}{ Mean + 1 SE } & \multicolumn{2}{|c|}{ Range } & \multirow{2}{*}{$\begin{array}{c}\text { Median } \\
23\end{array}$} & \multicolumn{2}{|c|}{ Mean + 1 SE } & \multicolumn{2}{|c|}{ Range } & \multirow{2}{*}{$\begin{array}{c}\text { Median } \\
19\end{array}$} \\
\hline Number of Taxa & 23 & \pm 1 & 8 & -38 & & 20 & \pm 1 & 1 & -43 & \\
\hline Hilsenhoff Biotic Index* & & \pm 0.1 & & -7.2 & 4.2 & & \pm 0.2 & & -7.5 & 4.3 \\
\hline Percent of Chironomidea & 31 & \pm 2 & 0 & -59 & 30 & 26 & \pm 2 & 0 & -59 & 25 \\
\hline Percent of Depositional Individuals & 37 & \pm 1 & 24 & -50 & 36 & 43 & \pm 2 & 14 & -67 & 45 \\
\hline Percent of EPT Individuals & 35 & \pm 4 & 2 & -78 & 35 & 36 & \pm 4 & 1 & -89 & 35 \\
\hline Percent of EPT Taxa & 35 & \pm 2 & 17 & -55 & 36 & 35 & \pm 2 & 13 & -60 & 36 \\
\hline Percent of Filters & 24 & \pm 3 & 0 & -58 & 23 & 16 & \pm 2 & 0 & -68 & 12 \\
\hline Percent of Gatherers & 50 & \pm 4 & 11 & -97 & 43 & 67 & \pm 3 & 21 & -99 & 68 \\
\hline Percent of Herbivore & 5 & \pm 1 & 0 & -37 & 3 & 7 & \pm 1 & 0 & -31 & 4 \\
\hline Percent of Predators & 2 & \pm 0 & 0 & -10 & 1 & 5 & \pm 1 & 0 & -29 & 2 \\
\hline Percent of Scrapers & 17 & \pm 3 & 0 & -45 & 12 & 2 & \pm 1 & 0 & -23 & 1 \\
\hline Percent of Top Two Taxa Individuals & 54 & \pm 3 & 23 & -94 & 52 & 60 & \pm 3 & 26 & -94 & 62 \\
\hline
\end{tabular}

*Hilsenhoff biotic index (Hilsenhoff, 1987) is a weighted average of tolerance values of arthropods and has possible index values from 0 to 10 , with higher values indicating poorer water quality. EPT = Ephemeroptera, Plecoptera, and Trichoptera.

TABLE 4. Results of Canonical Correspondence Analysis (CCA) of the Influence of Instream and Watershed Factors on Macroinvertebrate Composition for Riffle and Snag Samples.

\begin{tabular}{|c|c|c|c|c|c|}
\hline CCA I & $\mathbf{r}$ & CCA II & $\mathbf{r}$ & CCA III & $\mathbf{r}$ \\
\hline \multicolumn{6}{|c|}{ Riffle Samples } \\
\hline \multicolumn{6}{|c|}{ Environmental Variables* } \\
\hline Percent of Watershed Imperviousness & 0.44 & Minimum July Temperature & 0.69 & Watershed Barren Land & 0.40 \\
\hline Maximum Seven-Day temperature & 0.32 & Maximum Seven-Day Temperature & 0.66 & Minimum July & \\
\hline Percent of Detritus Substrate & 0.32 & Watershed Imperviousness & 0.49 & Temperature & 0.32 \\
\hline \multicolumn{6}{|c|}{ Macroinvertebrate Variables* } \\
\hline Percent of Gatherers & 0.54 & Percent of Herbivore & 0.59 & Percent of EPT Individual & -0.20 \\
\hline Percent of Scrapers & -0.54 & $\mathrm{HBI}$ & 0.36 & & \\
\hline Percent of EPT Individuals & -0.45 & Percent of EPT Taxa & -0.27 & & \\
\hline Percent of Filterers & -0.22 & Percent of Predator & 0.22 & & \\
\hline Percent of EPT Taxa & -0.20 & Percent of Chironomidae & 0.21 & & \\
\hline \multicolumn{6}{|c|}{ Snag Samples } \\
\hline \multicolumn{6}{|c|}{ Environmental Variables* } \\
\hline Maximum Seven-Day Temperature & 0.43 & Maximum Seven-Day Temperature & 0.47 & Percent of Gravel & 0.43 \\
\hline Conductivity & 0.31 & Watershed Imperviousness & 0.46 & Stream Sinuosity & 0.39 \\
\hline Percent of Watershed Imperviousness & 0.31 & & & Watershed Wetland & 0.33 \\
\hline \multicolumn{6}{|c|}{ Macroinvertebrate Variables* } \\
\hline Percent of Filterers & -0.47 & Percent of Predator & 0.37 & Percent of Top Two Taxa Individuals & -0.30 \\
\hline Percent of EPT Individuals & -0.30 & HBI & 0.31 & & \\
\hline Percent of Scrapers & -0.28 & & & & \\
\hline Percent of Gatherers & 0.27 & & & & \\
\hline Number of Taxa & -0.27 & & & & \\
\hline
\end{tabular}

*The habitat variables listed had correlations ( $r$ ) for the first three axes $>0.31$. The macroinvertebrate variables listed are those with $>20$ percent of their variance explained, with sign indicating the direction of their correlation with the CCA axis. 
The plot between the first and second CCA axes also identified that stream temperature and watershed imperviousness were the dominant environmental factors associated with snag macroinvertebrate communities (Figure 2).

\section{Riffle habitat}

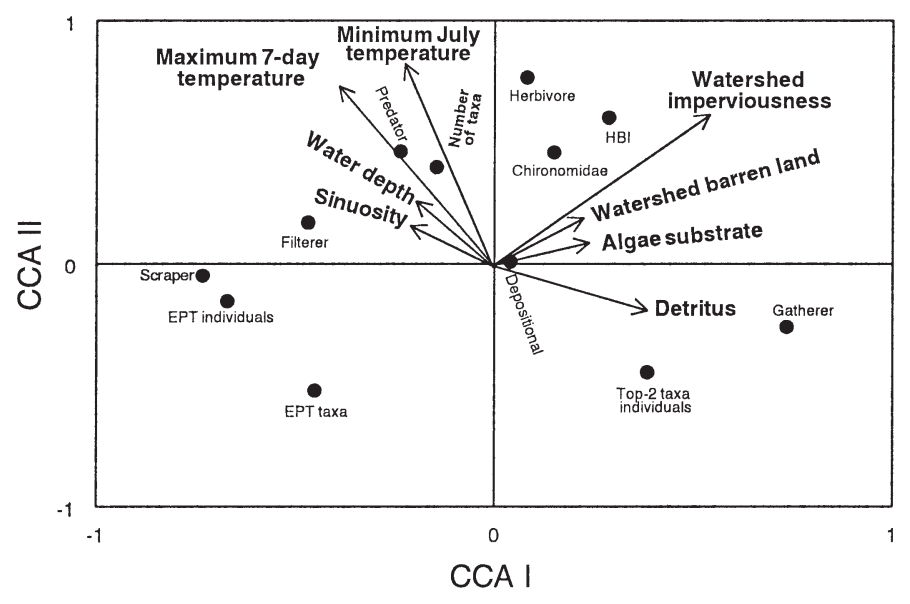

\section{Snag habitat}

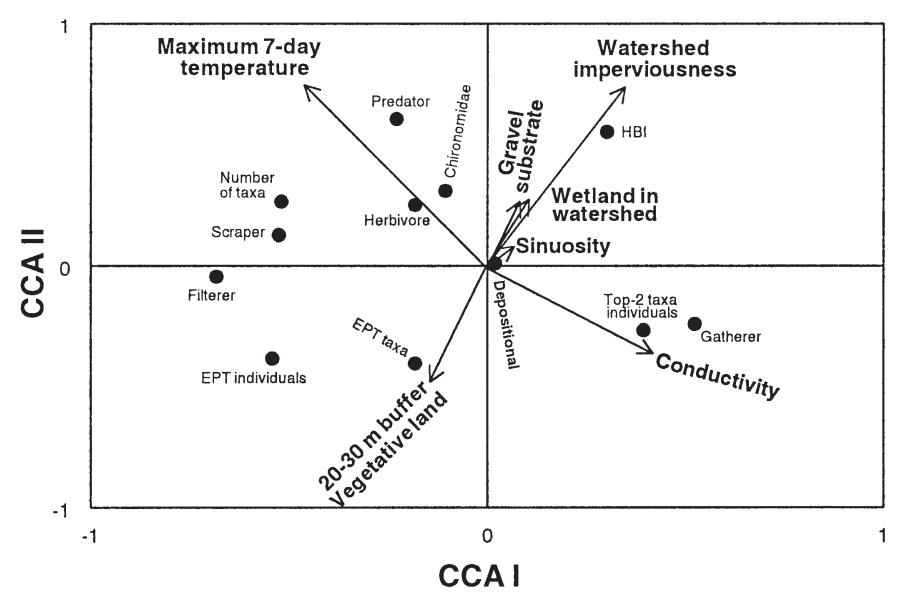

Figure 2. Plots of the First Two Axes From Canonical Correspondence Analysis Between Environmental Variables, Which Were Selected Using Stepwise Forward Selection Procedures, and Macroinvertebrate Assemblage Measures From Riffle and Snag Habitats. HBI $=$ Helsenhoff biotic index and EPT $=$ Ephemeroptera, Plecoptera, and Trichoptera.

Plots between two of the most significant environmental variables (watershed imperviousness and water temperature) and the selected macroinvertebrate variables revealed some obvious trends (Figure 3 ). The HBI scores increased linearly with stream temperature, and this relationship was much tighter for riffle than for snag samples. The percentages of EPT taxa, filterers, and gatherers decreased as stream temperature increased. The other macroinvertebrate variables did not show a clear relation with stream temperature. The HBI scores also increased linearly as watershed urban land use increased. Percentages of EPT individuals, EPT taxa, filterers, and scrapers showed nonlinear relations with levels of watershed urban land use. At low levels of watershed urbanization, both high and low values of these macroinvertebrate variables were observed. When watershed effective imperviousness exceeded 7 percent, the values of these macroinvertebrate variables were inevitably low. The relation between scrapers and urban land use was apparent for riffle samples only, and no obvious relation was observed between gatherer macroinvertebrates and urban land use.

\section{Influence of Different Spatial Scales of Land Uses on Macroinvertebrate Communities}

Our RDA analysis showed that the different scales of land use altogether explained 69 percent of the variation for riffles and 57 percent of the variation for snag macroinvertebrate measures (Figure 4). Land uses within and outside the $30 \mathrm{~m}$ buffer explained a similar amount of variation for riffle macroinvertebrates (31 percent versus 28 percent), whereas land use within the $30 \mathrm{~m}$ buffer explained slightly more variation for macroinvertebrates from snags than did land use outside the $30 \mathrm{~m}$ buffer (32 percent versus 25 percent). Our RDA analysis indicated that the threebuffer scale land uses alone explained 40 percent of the variation for riffle and 32 percent for snag macroinvertebrate communities. Of this explained variation, the land uses in the three buffer zones explained a similar amount of variation for riffle macroinvertebrate samples (27 to 29 percent), whereas land use within 0 to $10 \mathrm{~m}$ buffer explained substantially more variation (34 percent) than did the land use in 10 to $20 \mathrm{~m}$ ( 25 percent) or 20 to $30 \mathrm{~m}$ (23 percent) buffer zones for snag samples.

\section{DISCUSSION}

\section{Key Environmental Factors That Affect \\ Macroinvertebrate Communities}

Our study identified that summer stream temperature and the level of watershed urbanization were the two most influential factors in determining cold water stream macroinvertebrate assemblages for both riffle 

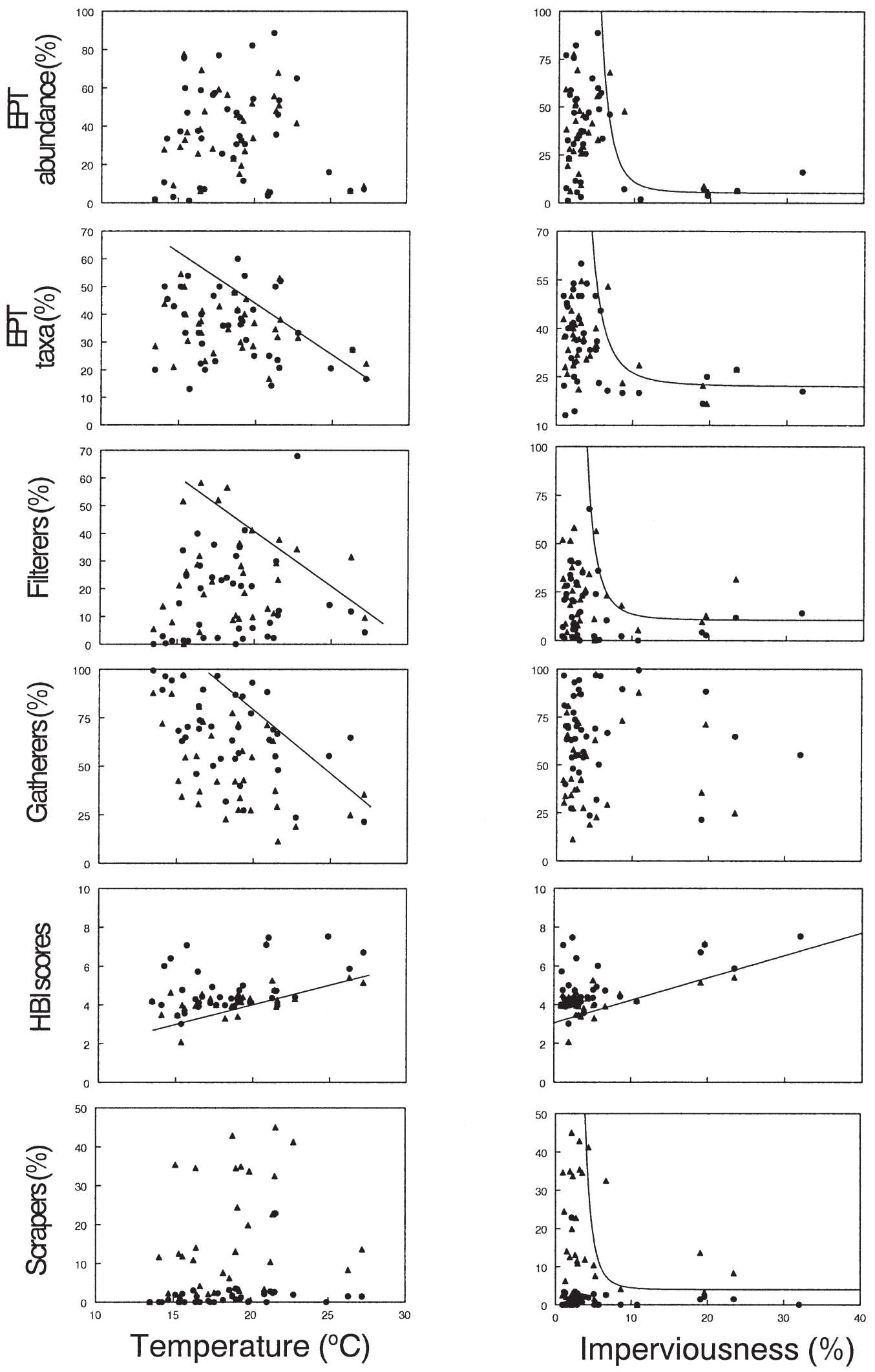

Figure 3. Plots Between Stream Maximum 7-Day Mean Temperature, Percent Watershed Effective Imperviousness and Selected Macroinvertebrate Assemblage Measures From Riffle (filled triangles) and Snag (filled circles) Habitats. The regression lines between temperature and HBI and between imperviousness and HBI were fitted by 10 percent quantile regressions. The rest of the lines were fitted by 90 percent quantile regression. HBI = Hilsenhoff biotic index and EPT = Ephemeroptera, Plecoptera, and Trichoptera. 
and snag habitats. Although these two factors were significantly correlated, urban land use explained only a small portion (32 percent) of the variation in stream temperature, indicating that other factors, such as stream width and shading, may also influence stream temperature. For the study streams, water temperature and urban land use each influenced different components of the macroinvertebrate assemblage. Urban land use mainly affected values of macroinvertebrate tolerance measures (i.e., positively associated with HBI scores and negatively correlated to EPT abundance). In contrast, stream temperature predominantly influenced taxa richness, and the relative abundance of functional feeding groups was positively correlated with percentage of predators and taxa richness and negatively correlated with percentages of gatherers and two most numerous taxa individuals. These results emphasize the fundamental role of water temperature in determining cold water macroinvertebrate assemblages.

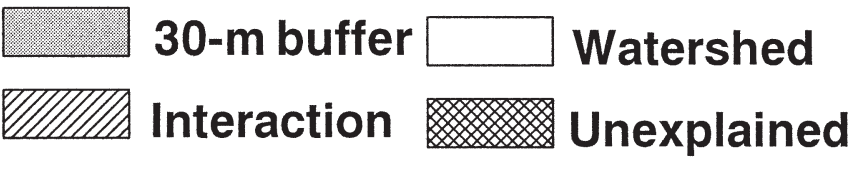

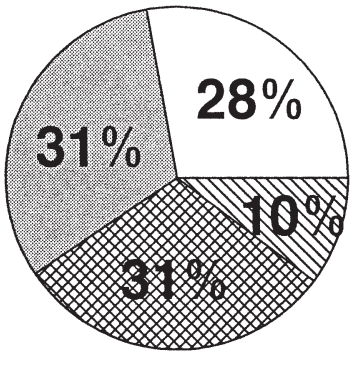

Riffle habitat

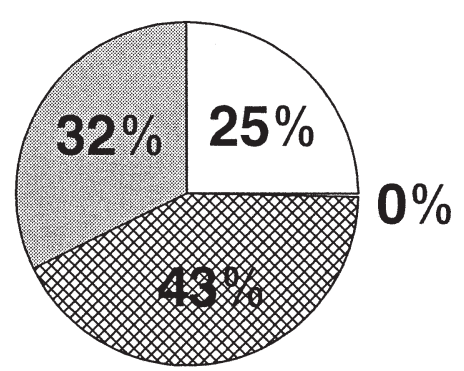

Snag habitat

\begin{abstract}
Figure 4. Percents of Variation for the Macroinvertebrate Assemblage Measures That Were Explained by Land Uses Within the $30 \mathrm{~m}$ Riparian Area, in the Watershed Outside the $30 \mathrm{~m}$ Zone, and by Land Uses in These Two Areas Jointly.
\end{abstract}

The other environmental factors strongly associated with macroinvertebrate assemblages were different between riffle and snag habitats. For riffle samples, macroinvertebrate assemblages were strongly associated with detritus, water depth, algae, and barren land, whereas macroinvertebrate assemblages from snag habitat were correlated mainly with water conductivity, riparian vegetated land use, watershed wetland, and gravel substrate. Although macroinvertebrate data from both riffle and snag habitats showed a similar urban degradation trend, our results imply that the mechanisms regulating macroinvertebrate assemblages differ between the two habitat types.

The fundamental regulatory mechanisms of water temperature in determining macroinvertebrate natural distributions have been well documented, but the influence of urbanization on water temperature regimes and hence on macroinvertebrates are less studied. Vannote and Sweeney (1980) synthesized site specific new and geographically broad published data and concluded that local and geographic thermal variation of rivers was a primary force controlling the composition, development, and function of aquatic insect communities. Many studies that examined variation in stream macroinvertebrate assemblages across broad spatial scales found that temperature was related to variation in assemblage structure (e.g., Bunn et al., 1986; Moss et al., 1987; Quinn and Hickey, 1990; Marchant et al., 1994). Because temperature affects the growth, metabolism, reproduction, emergence, and distribution of stream macroinvertebrates (Vannote and Sweeney, 1980), if watershed human activities have modified the natural stream thermal regimes, we then expect a modified macroinvertebrate assemblage. These previous findings are consistent with ours in that stream temperature has a strong influence on macroinvertebrate community structure and function.

Our finding that urban land use has a stronger influence on macroinvertebrates than channel morphology, substrate, or water quality measures is not surprising. Previous studies have yielded similar findings, although these studies did not consider multiple spatial scales simultaneously. Jones and Clark (1987) studied 22 streams in northern Virginia and found that percent abundance of the order Diptera, a relatively tolerant group, was 12 to 36 percent at rural sites, 14 to 66 percent at moderately urbanized sites, and 33 to 99 percent at heavily urbanized sites. In North Carolina, the relative abundance of EPT was an order of magnitude lower in an urban stream than in either a forested or an agricultural stream (Lenat and Crawford, 1994). Kemp and Spotila (1997) reported that Amphipoda, Ephemeroptera, Chironomidae, Plecoptera, and Trichoptera were more abundant at a rural Pennsylvania stream and Isopoda and Oligochaeta dominated at an urbanized stream. Stepenuck et al. (2002) studied 43 warm water streams in Wisconsin and found that watershed urbanization level was negatively correlated with EPT abundance and positively correlated with the HBI. They also found that many of the macroinvertebrate measures negatively correlated with urban land use were positively correlated with agricultural land. These results, in conjunction with ours, indicate that urban land use 
has a dominating influence on stream macroinvertebrate assemblages in comparison with other land uses.

Watershed urban land use also influences macroinvertebrate assemblages indirectly through its effects on local scale stream morphology, substrate, and physicochemical properties. Richards and Host (1994) evaluated relations between macroinvertebrate assemblages and environmental factors at separate spatial scales for streams on the north shore of Lake Superior. They reported that substrate embeddedness and size, woody debris, algal abundance, stream width, amount of run habitat, degree of shading, and sinuosity were local scale habitat variables that explained macroinvertebrate assemblages and that five of these eight local variables correlated with watershed urban and agriculture land uses. Richards et al. (1997) also reported that cross-sectional areas at bankfull discharge, percent shallow, slow water habitats, and percent fines were the most important local factors for predicting macroinvertebrate species traits in 45 nonurban Michigan streams. They found that catchment features, in particular surficial geology, influenced macroinvertebrate assemblages through their control over channel morphology and hydrology and that the effects of agricultural land use were masked by geology and lack of precision in land use data. Our results support the idea that large scale land use and catchment characteristics are key determinants of macroinvertebrate assemblages.

\section{Relations Between Key Environmental Factors and Macroinvertebrate Measures}

Linear relations between stream temperature and several macroinvertebrate measures were observed. However, the relations between stream temperature and EPT taxa or filterers became apparent only when the upper boundaries of the data distribution were examined. This is because factors other than temperature also affected these macroinvertebrate measures and introduced considerable variation below the upper boundary, resulting in wedge shaped data distributions. Using multiple linear regression, Sponseller et al. (2001) examined data from nine forest agriculture dominated watersheds in southwestern Virginia and found that maximum summer water temperature negatively correlated with total macroinvertebrate taxa and EPT taxa and positively correlated with percent of five dominant taxa. Using a multivariate approach, Griffith et al. (2001) evaluated data from 86 watersheds with some extent of agricultural disturbance in the southern Rockies ecoregion and also reported that stream temperature was associated with macroinvertebrate assemblage measures.
Our study implies that streams in rural watersheds with little or no urbanization may have highly variable macroinvertebrate assemblages, but at least some of these streams are in fair to good condition, The effects of urbanization on stream macroinvertebrates are manifested at surprisingly low levels of imperviousness. The initial apparent impact is about 7 percent effective imperviousness, and beyond that macroinvertebrate conditions are inevitably poor.

Our findings on the relationship between watershed urbanization and macroinvertebrate assemblages are remarkably consistent with those across the United States. In the Mid-Atlantic states, Klein (1979) studied macroinvertebrates in 13 streams in the Maryland Piedmont. Five watersheds with total imperviousness between 0 to 1 percent had 9 to 19 macroinvertebrate taxa. The remaining eight watersheds with imperviousness between 17 to 56 percent had two to eight taxa. Schueler and Galli (1992) examined 23 headwater stream sites in the Anacostia watershed, Maryland, and found that all stream sites with less than 10 percent total imperviousness had good to fair macroinvertebrate diversity. Nearly all sites with 12 percent or more impervious area had poor diversity. Jones and Clark (1987) monitored 22 stream sites in northern Virginia and concluded that macroinvertebrate diversity declined markedly after the watershed population density exceeded four or more individuals per acre. Shaver et al. (1994) analyzed data from 19 stream sites in Delaware and suggested that macroinvertebrate biological score dropped dramatically when imperviousness in watersheds increased above 8 to 15 percent. Beyond this imperviousness level, biological quality was consistently very low. In the Pacific Northwest, Horner et al. (1996) and May et al. (1997) determined that benthic invertebrate IBI scores declined sharply when total imperviousness increased from 5 to 12 percent. Scores were consistently low when imperviousness was greater than 12 percent in the Puget Sound lowlands of Washington state. In Wisconsin, Stepenuck et al. (2002) evaluated 43 warm water streams and found a substantial decrease in the Shannon diversity index, percentage of EPT individuals, taxa richness, and various feeding group variables and an increase in the HBI when effective imperviousness changed from 8 to 12 percent.

\section{Impacts of Spatial Distribution of Land Uses on Macroinvertebrate Communities}

We found that land uses closer to streams were more influential on macroinvertebrate assemblages than the same land uses located at distance. This phenomenon was more apparent for snag than for riffle 
samples. The function of natural riparian areas in protecting stream quality has been well documented (see reviews by Castelle et al., 1994; Lyons et al., 2000). The major roles of a natural riparian zone are to act as a buffer for reducing rapid runoff that can result in drastic increases in water levels and in frequency of flooding; to reduce sediments, nutrients, and toxicants being washed from terrestrial into the streams; to dampen fluctuations and extremes in water temperature; to protect banks from erosion and destabilization; and to provide food sources and habitat diversity for aquatic life.

The disproportionate influence of riparian land use relative to watershed land use has only been recognized in recent years. Because of the unavailability of high resolution and up-to-date land use data, earlier comparative studies were inconclusive (e.g., Richards and Host, 1994; Wang et al., 1997). With the development of more advanced geographic information systems and the increased availability of more precise and current land use databases, it has become increasingly clear that agricultural or urban activities in riparian areas can cause substantially more damage than the same activities away from stream channels. Richards et al. (1996) reported that land cover in riparian areas explained more variance in the percentage of stream fine substrate and in bank erosion and was more strongly associated with macroinvertebrate indices than land cover in the entire watershed. Lammert and Allan (1999) found that land use near the stream predicted biotic conditions better than regional land use in explaining the variability observed in fish and macroinvertebrates. Stewart et al. (2001) also reported that agriculture near streams had more influence on fish and macroinvertebrate communities than agriculture in other portions of the watershed. Wang et al. (2001) showed that urban land use within a $50 \mathrm{~m}$ buffer along the stream or within a $1.6 \mathrm{~km}$ radius upstream of the sampling sites had more influence on stream fish than did comparable urbanization farther away. Although the riparian area may seem insignificant in size relative to total watershed area, the aforementioned studies plus the results presented here indicate that protecting or restoring undisturbed buffer along urbanizing streams can offset some of the negative effects of watershed urban land use on stream ecosystems.

\section{SUMMARY}

Our study has indicated that the percentage of watershed urban land use is the most important environmental factor influencing cold water macroinvertebrate assemblages in urbanizing watersheds. Using impervious surface area as a measure of urbanization, we found that high quality index values for the macroinvertebrate measures were possible if effective imperviousness was less than 7 percent of the watershed area, but low quality values were inevitable above 10 percent imperviousness. Imperviousness levels between 7 percent and 10 percent represented a threshold urban development zone where minor changes in urbanization could result in major changes in cold water stream macroinvertebrate communities. Our study showed that this threshold zone is 1 to 2 percent lower and narrower in cold water streams than in warm water streams. Using a multivariate approach, we also found that land uses in the riparian area were equally or more influential relative to those in the rest of the watershed, although the riparian area comprised of only a small portion of the entire watershed.

Our study also suggests that water temperature is as important as urban land use in explaining characteristics of cold water macroinvertebrate assemblages in urbanizing watersheds. Although urban land use and water temperature are correlated, each influences different components of the macroinvertebrate community. Stream temperature and urban land use are the two most important factors shaping macroinvertebrate compositions for both riffle and snag habitats, but other influential factors differ between riffle and snag habitats. Detritus, percent algae, water depth, and percent watershed barren land are more important for macroinvertebrate assemblages in riffles, whereas water conductivity, riparian vegetated land, gravel substrate, and percent watershed wetland are more influential for those in snags. These results indicate that stream temperature may be one of the major factors through which human activities degrade streams. Additionally, macroinvertebrate data from snags, especially for low gradient streams without riffles, should not be interpreted in the same way as those from riffles because their macroinvertebrate assemblages are different and they respond to human disturbance differently.

Our results have several implications for watershed management. Urban development schemes that minimize the total amount of impervious areas and that avoid development in areas where major ground water recharge occurs should reduce the impact of urbanization on cold water streams. Urban watershed best management practices such as detention ponds should not only focus on reducing peak flows and increasing baseflow but also on maintaining natural ground water recharging rates and natural stream thermal regime. Because the impervious threshold zone is 1 to 2 percent lower and narrower in cold water than in warm water streams, low level urban development in watersheds can cause more damage to 
cold water streams than to warm water systems. Sufficient width of undeveloped buffers along riparian areas should be more beneficial in maintaining stream natural thermal regimes. Ultimately, however, the amount of impervious surface in the watershed will have to be limited if a healthy cold water stream system is to persist.

\section{ACKNOWLEDGMENTS}

We thank the Minnesota Department of Natural Resources (DNR) and the Minnesota Pollution Control Agency, especially Paul Wingate, Jason Moeckel, Scott Niemela, and Konrad Schmidt for helping select stream sites and giving permission for sampling streams in Minnesota. We also thank Roger Bannerman and Edward Emmons for providing research guidance and assistance on funding; Mary Botzet, Kerilynn Carden, Kevin Fassbind, Tad Griest, Deann Heckendorf, Ben Lenz, Elizabeth Miller, David Row, Carrie Scheele, and Zeb Zelensky for helping collect the macroinvertebrate and habitat data; Christopher Smith and Albert Martin for digitizing and gathering land use data; Stanley Szczytko and Jeffrey Dimick for identifying the macroinvertebrate samples through a contract between Wisconsin DNR and University of Wisconsin-Stevens Point. John Lyons, Matthew Mitro, Brian Weigel, and four anonymous reviewers provided insightful comments that substantially improved the manuscript. This project was jointly funded by the Bureau of Watershed Management and Bureau of Integrated Science Services, Fish and Habitat Research of Wiscon$\sin \mathrm{DNR}$

\section{LITERATURE CITED}

Allan, J. D. and L. B. Johnson, 1997. Catchment-Scale Analysis of Aquatic Ecosystems. Freshwater Biology 37:107-111.

Allan, J. D., D. L. Erickson, and J. Fay, 1997. The Influence of Catchment Land Use on Stream Integrity Across Multiple Spatial Scales. Freshwater Biology 37:149-161.

Arnold, C. L., Jr. and C. J. Gibbons, 1996. Impervious Surface Coverage: The Emergence of a Key Environmental Indicator. Journal of the American Planning Association 62(2):243-258.

Bunn, S. E., D. H. Edward, and N. R. Loneragan, 1986. Spatial and Temporal Variation in the Macroinvertebrate Fauna of Streams of the Northern Jarrah Forest, Western Australia: Community Structure. Freshwater Biology 16:67-91.

Carter, J. L., S. V. Fend, and S. S. Kennelly, 1996. The Relationships Among Three Habitat Scales and Stream Benthic Invertebrate Community Structure. Freshwater Biology 35:109-124.

Castelle, A. J., A. W. Johnson, and C. Conolly, 1994. Wetland and Stream Buffer Size Requirements - A Review. Journal of Environmental Quality 23:878-882.

Fitzpatrick, F. A., B. C. Scudder, B. N. Lenz, and D. J. Sullivan, 2001. Effects of Multi-Scale Environmental Characteristics on Agricultural Stream Biota in Eastern Wisconsin. Journal of the American Water Resources Association (JAWRA) 37:1489-1507.

Griffith, M. B., P. R. Kaufman, A. T. Herlihy, and B. H. Hill, 2001. Analysis of Macroinvertebrate Assemblages in Relation to Environmental Gradients in Rocky Mountain Streams. Ecological Application 11:489-505.

Hilsenhoff, W. L., 1987. An Improved Biotic Index of Organic Stream Pollution. Great Lake Entomologist 20:31-39.
Horner, R. R., D. B. Booth, A. A. Azous, and C. W. May, 1996. Watershed Determinants of Ecosystem Functioning. In: Effects of Watershed Development and Management on Aquatic Ecosystems, L. A. Roesner (Editor). Proceedings of the ASCE Conference, Snowbird, Utah, pp. 251-274.

Johnson, L. B. and S. Gage, 1997. Landscape Approaches to the Analysis of Aquatic Ecosystems. Freshwater Biology 37:113132.

Jones, R. C. and C. C. Clark, 1987. Impact of Watershed Urbanization on Stream Insect Communities. Water Resource Bulletin 23:1047-1055.

Karr, J. R. and E. W. Chu, 1999. Restoring Life in Running Water, Better Biological Monitoring. Island Press, Washington, D.C.

Kemp, S. J. and J. R. Spotila, 1997. Effects of Urbanization on Brown Trout Salmo trutta, Other Fishes and Macroinvertebrates in Valley Creek, Valley Forge, Pennsylvania. American Midland Naturalist 138:55-68.

Kerans, B. L. and J. R. Karr, 1994. A Benthic Index of Benthic Integrity (B-IBI) for Rivers of the Tennessee Valley. Ecological Application 4:768-785.

Klein, R. D., 1979. Urbanization and Stream Quality Impairment. Water Resources Bulletin 15:948-963.

Lammert, M. and J. D. Allan, 1999. Assessing Biotic Integrity of Streams: Effects of Scale in Measuring the Influence of Land Use/Cover and Habitat Structure on Fish and Macroinvertebrates. Environmental Management 23:257-270.

Lenat, D. R. and J. K. Crawford, 1994. Effects of Land Use on Water Quality and Aquatic Biota of Three North Carolina Piedmont Streams. Hydrobiologia 294:185-199.

Lillesand, T., J. Chipman, D. Nagel, H. Reese, M. Bobo, and R. Goldman, 1998. Upper Midwest Gap Analysis Image Processing Protocol. EMTC 98-G00, U.S. Geological Survey, EMTC, Onalaska, Wisconsin.

Lyons, J., 1996. Patterns in the Species Composition of Fish Assemblages Among Wisconsin Streams. Environmental Biology of Fishes 45:329-341.

Lyons, J., S. W. Trimble, and L. K. Paine, 2000. Grass Versus Trees: Managing Riparian Areas to Benefit Streams of Central North America. Journal of the American Water Resource Association (JAWRA) 36:919-930.

Marchant, R., L. A. Barmuta, and B. C. Chessman, 1994. Preliminary Study of the Ordination and Classification of Macroinvertebrate Communities From Running Waters in Victoria, Australia. Australia Journal of Marine and Freshwater Research 45:945-962.

May, C. W., R. R. Horner, J. R. Karr, B. W. Mar, and E. B. Welch, 1997. Effects of Urbanization on Small Streams in the Puget Sound Lowland Ecoregion. Watershed Protection Techniques 2:485-494.

Merritt, R. W. and K. W. Cummins, 1984. An Introduction to the Aquatic Insects of North American (Second Edition). Kendall/Hunt Publishing Company, Dubuque, Iowa.

Minshall, G. W., 1988. Stream Ecosystem Theory: A Global Perspective. Journal of North American Benthology Society 7:263288.

Moss, D., M. T. Furse, J. F. Wright, and P. D. Armitage, 1987. The Prediction of the Macroinvertebrate Fauna of Unpolluted Running-Water Sites in Great Britain Using Environmental Data. Freshwater Biology 17:41-52.

Paul, M. J. and J. L. Meyer, 2001. Streams in the Urban Landscape. Annual Review of Ecology and Systematics 32:333-365.

Quinn, J. M. and C. W. Hickey, 1990. Characterization and Classification of Benthic Invertebrate Communities in 88 New Zealand Rivers in Relation to Environmental Factors. New Zealand Journal of Marine and Freshwater Research 24:387-409. 
Richards, C. and G. Host, 1994. Examining Land Use Influences on Stream Habitats and Macroinvertebrates: A GIS Approach. Water Resource Bulletin 30:729-738.

Richards, C., L. B. Johnson, and G. E. Host, 1996. Landscape-Scale Influences on Stream Habitat and Biota. Canadian Journal of Fisheries and Aquatic Science 53(Suppl. 1):295-311.

Richards, C. B., R. J. Haro, L. B. Johnson, and G. E. Host, 1997. Catchment and Reach-Scale Properties as Indicators of Macroinvertebrate Species Traits. Freshwater Biology 37:219230.

Roth, N. E., J. D. Allan, and D. L. Erickson, 1996. Landscape Influences on Stream Biotic Integrity Assessed at Multiple Spatial Scales. Landscape Ecology 11(3):141-156.

Schueler, T., 1994. The Importance of Imperviousness. Watershed Protection Techniques 1(3):100-111.

Schueler, T. and J. Galli, 1992. Environmental Impacts of Stormwater Ponds. In: Watershed Restoration Source Book. Anacostia Restoration Team, Metropolitan Washington Council of Governments, Washington D.C.

Seelbach, P. W., M. J. Wiley, J. C. Kotanchik, and M. E. Baker, 1997. A Landscape-Based Ecological Classification System for River Valley Segments in Lower Michigan. State of Michigan, Department of Natural Resources, Fisheries Division, Research Report Number 2036.

Shaver, E., J. Maxted, G. Curtis, and D. Carter, 1994. Watershed Protection Using an Integrated Approach. In: Proceedings From Stormwater NPDES Related Monitoring Needs. Mount Crested Butte, Colorado, American Society of Civil Engineers.

Simonson, T. D., J. Lyons, and P. D. Kanehl, 1994. Guidelines for Evaluating Fish Habitat in Wisconsin Streams. U.S. Department of Agriculture, Forest Service, North Central Forest Experiment Station, St. Paul, Minnesota, General Technical Report NC-164, St. Paul, Minnesota.

Southwood, T. R. E., 1977. Habitat, the Templet for Ecological Strategies? Journal of Animal Ecology 46:337-365.

Sponseller, R. A., E. F. Benfield, and H. M. Valett, 2001. Relationships Between Land Use, Spatial Scale and Stream Macroinvertebrate Communities. Freshwater Biology 46:1409-1424.

Steedman, R. J., 1988. Modification and Assessment of an Index of Biotic Integrity to Quantify Stream Quality in Southern Ontario. Canadian Journal of Fisheries and Aquatic Sciences 45:492-501.

Stepenuck, K. F., R. L. Crunkilton, and L. Wang, 2002. Impacts of Urban Land Use on Macroinvertebrate Communities in Southeastern Wisconsin Streams. Journal of the American Water Resources Association (JAWRA) 38:1041-1051.

Stewart, J. S., L. Wang, J. Lyons, J. A. Horwatich, and R. Bannerman, 2001. Influences of Watershed, Riparian-Corridor, and Reach-Scale Characteristics on Aquatic Biota in Agricultural Watersheds. Journal of the American Water Resources Association (JAWRA) 37:1475-1487.

ter Braak, C. J. F. and P. Smilauer, 1998. CANOCO Reference Manual and User's Guide to Canoco for Windows: Software for Canonical Community Ordination (Version 4). Microcomputer Power, Ithaca, New York.

Townsend, C. R. and A. G. Hildrew, 1994. Species Traits in Relation to a Habitat Templet for River Systems. Freshwater Biology 31:265-275.

Vannote, R. L. and B. W. Sweeney, 1980. Geographic Analysis of Thermal Equilibria: A Conceptual Model for Evaluating the Effect of Natural and Modified Thermal Regimes on Aquatic Insect Communities. The American Naturalist 115:667-695.
Wang, L. and J. Lyons, 2003. Fish and Benthic Macroinvertebrate Assemblages as Indicators of Stream Degradation in Urbanizing Watersheds. In: Biological Response Signatures: Multimetric Index Patterns for Assessment of Freshwater Aquatic Assemblages, T. P. Simon (Editor). CRC Press, Boca Raton, Florida, pp. 227-249.

Wang, L., J. Lyons, and P. Kanehl, 2003. Impacts of Urban Land Use on Trout Streams in Wisconsin and Minnesota. Transactions of the American Fisheries Society 132(4):825-839.

Wang, L., J. Lyons, P. Kanehl, and R. Bannerman, 2001. Impacts of Urbanization on Stream Habitat and Fish Across Multiple Spatial Scales. Environmental Management 28:255-266.

Wang, L., J. Lyons, P. Kanehl, and R. Gatti, 1997. Influences of Watershed Land Use on Habitat Quality and Botic Integrity in Wisconsin Streams. Fisheries 22(6):6-12.

Wang, L., T. D. Simonson, and J. Lyons, 1996. Accuracy and Precision of Selected Stream Habitat Estimates. North American Journal of Fisheries Management 16:340-347.

Wiley, M. J., S. L. Kohler, and P. W. Seelbach, 1997. Reconciling Landscape and Local Views of Aquatic Communities: Lessons From Michigan Trout Streams. Freshwater Biology 37:133-148.

Wright, J. F., D. Moss, P. D. Armitage, and M. T. Furse, 1984. A Preliminary Classification of Running-Water Sites in Great Britain Based on Macroinvertebrate Species and the Prediction of Community Type Using Environmental Data. Freshwater Biology 14:221-256. 